Acknowledgments. The authors thank Dr. Andrew Husczuk for his insightful criticism of this manuscript.

\section{REFERENCES}

1. Åstrand P-O 1952 Experimental Studies of Physical Working Capacity in Relation to Sex and Age. Muskgaard, Copenhagen, $171 \mathrm{pp}$

2. Åstrand P-O, Rodahl K 1977 Textbook of Work Physiology, ed 2. McGrawHill Book Co. New York, pp 367-388

3. Bar-Or O. Shepard RJ, Allen CJ 1971 Cardiac output of 10- to 13-year-old boys and girls during submaximal exercise. J Appl Physiol 30:219

4. Beaver WL, Lamarra N, Wasserman K 1981 Breath-by-breath measurement of true alveolar gas exchange. J Appl Physiol Respir Environ Exercise Physiol $51: 1662$

5. Cook JD, Finch CA, Smith NJ 1976 Evaluation of the iron status of a population. Blood 48:449

6. Cooper DM. Weiler-Ravell D, Whipp BJ, Wasserman K 1984 Aerobic parameters of exercise as a function of body size during growth in children. J Appl Physiol Respir Environ Exercise Physiol 53:628

7. Davies CTM, Sargeant JA 1975 Effects of training on the physiological responses to one- and two-leg work. J Appl Physiol 38:377

8. Davis JA, Whipp BJ, Lamarra N, Huntsman DJ, Frank MH, Wasserman K 1982 Effect of ramp slope on determination of aerobic parameters from the ramp exercise test. Med Sci Sports Exercise 14:339

9. Godfrey S, Davies CTM, Wozniak E, Barnes CA 1971 Cardiorespiratory response to exercise in normal children. Clin Sci 40:419

10. Kleiber M 1961 The Fire of Life. John Wiley and Sons, New York, pp $177-$ 225
11. Lamarra N 1982 Ventilatory control, cardiac output, and gas-exchange dynamics during exercise transients in man. Ph.D. dissertation, Dept of Engineering, University of California, Los Angeles

12. Malina RM 1978 Growth of muscle tissue and muscle mass. In: Falkner F Tanner JM (eds) Human Growth, vol 2. Plenum Press, New York, pp 273294

13. Marshall WA 1978 Puberty. In: Falkner F, Tanner JM (eds) Human Growth, vol 2. Plenum Press, New York, pp 141-178

14. Schmidt-Nielsen K 1977 Problems of scaling: locomotion and physiological correlates. In: Pedley TJ (ed) Scale Effects in Animal Locomotion. Academic Press, London, $560 \mathrm{pp}$

15. Sproul A, Simpson E 1964 Stroke volume and related hemodynamic data in normai children. Pediatrics 33:912

16. Taylor CR, Maloiy GMO, Weibel ER, Langman VA, Kamau JMZ, Seeherman JH, Heglund NC 1981 Design of the mammalian respiratory system. III. Scaling maximum aerobic capacity to body mass: wild and domestic mammals. Respir Physiol 44:25

17. Taylor CR. Weibel ER 1981 Design of the mammalian respiratory system. I. Probl:m and strategy. Respir Physiol 44:1

18. Wallensiein S, Zucker CL. Fleiss JL 1980 Some statistical methods useful in circulation research. Circ Res 47:1

19. Wasserman K, Whipp BJ, Davis JA 1981 Respiratory physiology of exercise metabolism, gas exchange, and ventilatory control. Int Rev Physiol 23:180

20. Wasserman K. Whipp BJ, Koyal SN, Beaver WL 1973 Anaerobic threshold and respiratory gas exchange during exercise. J Appl Physiol 35:236

21. Whipp BJ, Davies JA, Torres F, Wasserman K 1981 A test to determine parameters of aerobic function during exercise. J Appl Physiol Respir Environ Exercise Physiol 50:217

\title{
The Relationship between the Branched Chain Amino Acids and Their $\alpha$-Ketoacids in Maple Syrup Urine Disease
}

\author{
SELMA E. SNYDERMAN, FRED GOLDSTEIN, CLAUDE SANSARICQ, AND \\ PATRICIA M. NORTON* \\ Department of Pediatrics, New York University Medical Center, New York, New York 10016
}

\section{Summary}

Plasma branched chain amino acid levels and their respective ketoacid analogues were determined in seven maple syrup urine disease patients ranging in age from $12 \mathrm{~h}$ to 12 years. One hundred one pairs were analyzed. There was a high degree of correlation between the amino acid and its ketoacid analogue at every amino acid level. The coefficient of correlation $(0.84)$ was highest for leucine- $\alpha$-ketoisocaproic acid. The ratio of ketoacid analogue to amino acid, $(0.87)$, was also the greatest for leucine. The close correlation implies that adequate monitoring for therapy can be accomplished by the use of the technically simpler and more rapid determination of the plasma branched chain amino acids.

Received August 22, 1983; accepted February 7, 1984.

Correspondence may be addressed to Selma E. Snyderman, M.D., Department of Pediatrics, New York University Medical Center, 550 First Avenue, New York, New York 10016.

Supported by Grant MCJ-000317, Office for Maternal and Child Health, Bureau of Community Health Services, Health Service Administration, Department of Health, Education, and Welfare.

* Deceased.
Maple syrup urine disease (branched chain ketoacidemia) in its classical form is a devastating disease. Untreated, it results in rapid neurologic deterioration and death in the first weeks of life. It is the consequence of a defect in the metabolism of the branched chain amino acids. The first step, transamination, takes place normally, but there is failure of the second step, oxidative decarboxylation. As a result, there is accumulation of both the branched chain amino acids and their ketoacid analogues in a number of body fluids. One of the still unexplained findings in this disease has been the much greater abnormality of the plasma leucine level than that of the other two branched chain amino acids. This is of special importance because the appearance of clinical symptoms can be most closely related to the degree of elevation of the plasma leucine level; we have been able to document this relationship in our treatment of over 20 cases. In addition, study of animal tissue homogenates and brain slices has demonstrated the toxic effect of $\alpha$-ketoisocaproic acid, the derivative of leucine. Inhibition of 1-glutamic acid decarboxylase (24), depressed oxygen utilization (8), and inhibition of pyruvate oxidation have been reported (1).

Very few quantitative determinations of the individual branched chain keto acids in the plasma have been performed 
in this disease because of technical difficulties. We undertook a study of these derivatives in order to determine if these levels could be related to those of the branched chain amino acids in the plasma, and if they might account for the different degree of abnormality of these amino acids.

\section{SUBJECTS AND METHODS}

The subjects were seven infants and children with classical maple syrup urine disease as determined by the degree of branched chain amino acid elevation at the time of diagnosis, the degree of enzyme deficiency, and the clinical course. Three were studied in the neonatal period at the time of diagnosis and all were studied when there was biochemical and clinical relapse as a result of an intercurrent infection. The patients ranged in age from $12 \mathrm{~h}$ to 12 years at the time of study, and there were four males and three females in the group. Informed consent was obtained from the parents of all the patients.

All plasma amino acid levels were determined with a Beckman $121 \mathrm{M}$ analyzer according to the method of Piez and Morris (19). Ketoacid analogues were determined by a modification of the method of Langenbeck et al. (11); recovery by this method is over $81 \%$. Molar response factors were determined in the original description of the method by the addition of a wide range of concentration of $\alpha$-ketoacids and of an internal standard to urine samples. This was repeated in the present study with the addition of similar concentrations of $\alpha$-ketoacids to normal plasma samples. Similar results were obtained.

\section{RESULTS}

One hundred one pairs of the branched chain amino acids and their $\alpha$-keto analogues were determined. There was a definite correlation between the amino acid and its ketoacid analogue at all levels of the amino acid. Leucine levels ranged between 0.7 and $69 \mathrm{mg} / \mathrm{dl}$, isoleucine between 0.1 and $11 \mathrm{mg} / \mathrm{dl}$, alloisoleucine between 0.8 and $5.8 \mathrm{mg} / \mathrm{dl}$, and valine between 0.4 and 17.9 $\mathrm{mg} / \mathrm{dl} . \alpha$-Ketoisocaproate acid levels were between 0.11 and 51.6, $\alpha$-keto- $\beta$-methylvaleric acid between 0.1 and 17 , and $\alpha$-ketoisovaleric acid levels between 0.1 and $3.9 \mathrm{mg} / \mathrm{dl}$. The degree of correlation was highest for leucine and $\alpha$-ketoisocaproate, 0.84 , $p<0.0001$; it was $0.77, p<0.0001$ for valine and $\alpha$-ketoisovalerate; and $0.74, p<0.0001$ for isoleucine, alloisoleucine and $\alpha$ keto $\beta$-methylvalerate. These results are expressed graphically in figures 1 to 3 .

The ratio of ketoacid to amino acid was much higher for leucine than for the other two pairs of amino-ketoacids. The majority of these ratios fell within very narrow limits; $85 \%$ of all values were within $1 \mathrm{SD}$ of the mean. The small number of values which lay at either extreme of the range occurred a similar number of times in all subjects.Average ratios, standard deviation, and range are listed in Table 1.

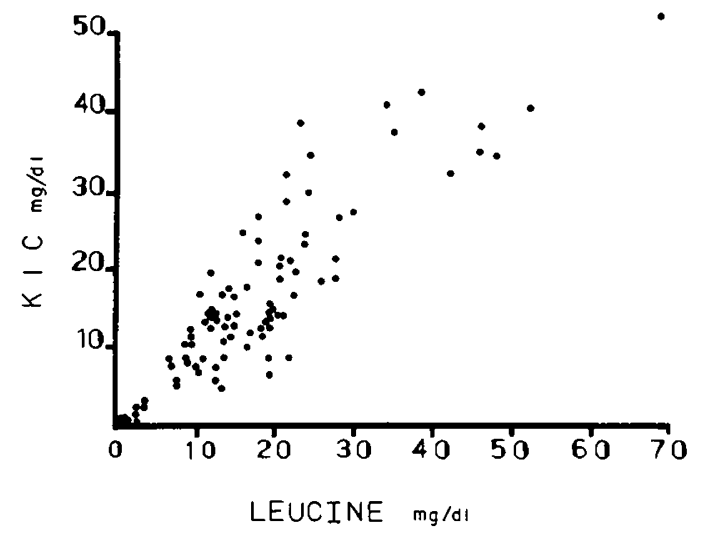

Fig. 1. The relationship of plasma $\alpha$-ketoisocaproate $(K I C)$ to leucine in maple syrup urine disease $(r=0.84 ; p<0.0001)$.

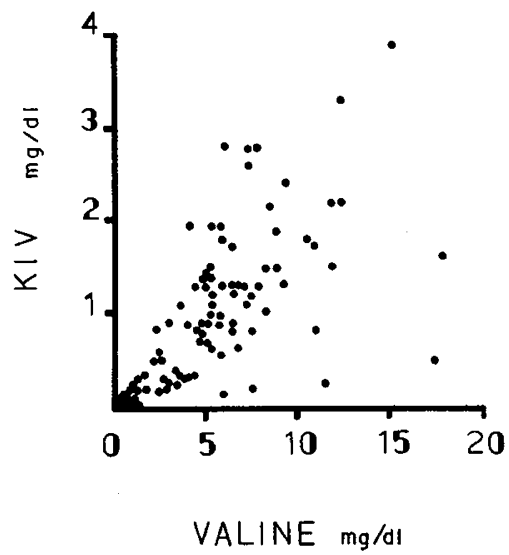

Fig. 2. The relationship of plasma $\alpha$-ketoisovalerate $(K I V)$ to valine $(r=0.77 ; p<0.0001)$.

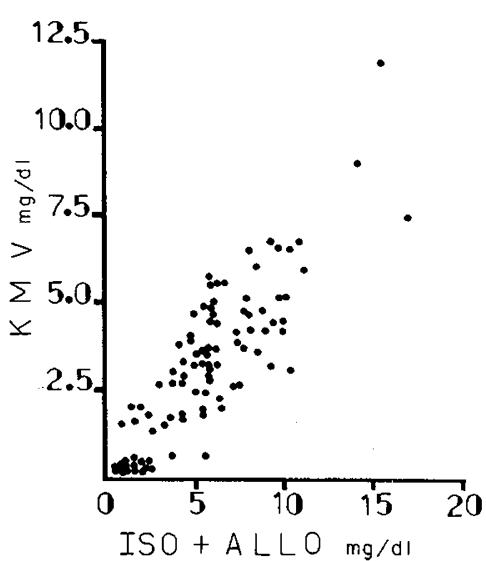

Fig. 3. The relationship of plasma $\alpha$-keto- $\beta$-methylvalerate ( $K M V$ ) to isoleucine and alloisoleucine $(r=0.74 ; p<0.0001)$.

Table 1. Ratio of ketoacid analogue to amino acid

\begin{tabular}{lcc}
\hline & Average and SD & Range \\
\hline$\alpha$-Ketoisocaproic acid/leucine & $0.87 \pm 0.34$ & $0.15-1.6$ \\
$\alpha$-Keto- $\beta$-methylvaleric acid/iso- & $0.58 \pm 0.21$ & $0.09-1.0$ \\
$\begin{array}{l}\text { leucine }+ \text { alloisoleucine } \\
\alpha \text {-Ketoisovaleric acid/valine }\end{array}$ & $0.19 \pm 0.11$ & $0.08-0.47$ \\
\hline
\end{tabular}

\section{DISCUSSION}

Our results do not confirm those of Lancaster et al. (10) who found that the ketoacid analogues do not accumulate until the level of each branched chain amino acid exceeds 0.8 to $1.0 \mathrm{mM}$ $(10.5-13 \mathrm{mg} / \mathrm{dl})$. This conclusion was based on a small number of samples and a technique with poor recoveries of ketoacid analogues in serum, which ranged from 42 to $52 \%$. Our findings do confirm those of Langenbeck et al. (13) who, in a smaller number of subjects and determinations, also found a close correlation between the branched chain amino acids and their corresponding ketoacid analogues.

In every instance, the value for the ketoacid analogue of leucine was the highest and that for the analogue of valine was the lowest. This is similar to the situation with the amino acids where leucine is always the most abnormal, and valine the least abnormal. The plasma branched chain amino acids in 22 infants at the time of diagnosis are summarized in Table 2 and demonstrate these differences quite strikingly. This also occurs whenever biochemical control is lost as a result of an intercurrent infection. These differences in branched chain amino acid accumulation cannot be ascribed to intake. Although there is more leucine then either valine or isoleucine in both cow's and human milk (7), the 
Table 2. Plasma branched chain amino acids at diagnosis*

\begin{tabular}{lccc}
\hline & $\begin{array}{c}\text { Leucine } \\
(\mathrm{mg} / \mathrm{dl})\end{array}$ & $\begin{array}{c}\text { Isoleucine }+ \\
\text { alloisoleucine } \\
(\mathrm{mg} / \mathrm{dl})\end{array}$ & $\begin{array}{c}\text { Valine } \\
(\mathrm{mg} / \mathrm{dl})\end{array}$ \\
\hline MSUD & $42.8 \pm 15.9$ & $12.1 \pm 3.47$ & $11.2 \pm 5.3$ \\
Normal & $1.3 \pm 0.59$ & $0.65 \pm 0.35$ & $2.0 \pm 0.61$ \\
MSUD/normal & 32.9 & 18.6 & 5.6 \\
\hline
\end{tabular}

* MSUD, maple syrup urine disease; mean \pm SD, 22 patients.

infant's requirement for leucine (23) is much higher than that for the other two branched chain amino acids $(21,22)$, and would thus compensate for the differences in intake.

There are several explanations for the lower level of the ketoacid derivative of valine. There is a greater formation of the hydroxy derivative of valine than of the other two amino acids (9); the mechanism for this has not yet been determined. The greater renal clearance of this derivative would also tend to lower the plasma concentration (12). In addition, there are several instances in which there was more residual decarboxylation of this amino acid (4). There is no similar explanation for the much less abnormal level of isoleucine. The combined isoleucinealloisoleucine level is usually only about one-third as abnormal as the leucine level.

There has been a great deal of investigation recently on the mechanism of action of the branched chain $\alpha$-ketoacid dehydrogenase but none of the findings offers an explanation for the observed differences in amino acid and ketoacid levels. The relative rates of decarboxylation seem to vary with the type of tissue preparation employed. With the use of isolated bovine liver mitochondria $(5,16)$, perfused rat heart $(2)$, and bovine kidney mitochondria (18), $\alpha$-ketoisovalerate was decarboxylated more rapidly than $\alpha$-ketoisocaproate. However, when isolated perfused rat liver was used, the rate of $\alpha$-ketoisocaproate oxidation exceeded that of $\alpha$-ketoisovalerate decarboxylation at all levels of substrate concentration studied (17). Coinfusion of either $\alpha$-ketoisovalerate or of $\alpha$-keto- $\beta$-methylvalerate inhibited the rate of $\alpha$-ketoisocaproate decarboxylation in both types of tissue preparation. Such inhibition might play a role in the accumulation of $\alpha$-ketoisocaproate if there were a significant degree of residual enzyme activity. A study utilizing a disrupted cell system obtained from fibroblasts of maple syrup urine disease patients demonstrated a decreased substrate affinity (3); the acitvity of the $E_{1}$ component of the dehydrogenase was dependent on the substrate concentration and approached 40 to $60 \%$ of normal at $5 \mathrm{mM}$ substrate. This concentration is considerably higher than the highest value observed in this present study. The other two ketoacid analogues were not studied; it is therefore possible that activation might occur at lower concentrations of substrate for these two derivatives. Clearly, much more information is needed about the exact nature of the enzyme deficits in this disorder; the effect of accumulated ketoacids on pyruvate dehydrogenase activity (25), one component of which may be the same as the $E_{3}$ component of the branched chain amino acid dehydrogenase, the possibility of acyl-CoA inhibition, and the influence of carnitine on the accumulation of these derivatives (14) are possible directions for further investigation of this disease.

The significantly higher ratio of $\alpha$-ketoisocaproic acid-leucine than of the other two ketoacid-amino acid pairs is also of some interest. Branched chain amino acid transaminase activity of isolated rat kidney has been increased by perfusion with $\alpha$ ketoisocaproate but not with either of the other two branched chain ketoacid analogues (15). This stimulation of transamination by $\alpha$-ketoisocaproate in addition to any inhibitory effect on decarboxylation by the other two branched chain ketoacid ana- logues might account for the greater accumulation of the leucine derivative.

The data reported do support the use of plasma levels of branched chain amino acids to monitor the therapy of maple syrup urine disease. The possibility that $\alpha$-ketoisocaproate is more toxic to the central nervous system than leucine $(6,20)$ has led to the suggestion that therapy might be improved by monitoring the ketoacids in preference to the amino acids. The close correlation found in this study does imply that adequate monitoring for therapy can be accomplished by the use of the technically simpler and more rapid determination of the plasma branched chain amino acids.

\section{REFERENCES}

1. Bowden JA, McArthur CL III, Fried M 1971 The inhibition of pyruvate decarboxylation in rat brain by alpha ketoisocaproic acid. Biochem Med 5:101

2. Buffington CK, DeBuysere MS, Olson MS 1979 Studies on the regulation of the branched chain $\alpha$-keto acid dehydrogenase in the perfused rat heart. J Biol Chem 254:10453

3. Chuang DT, Niu WL, Cox RP 1981 Activities of branched-chain 2-oxy acid dehydrogenase and its components in skin fibroblasts from normal and classical maple syrup urine disease subjects. Biochem J 200:59

4. Dancis J, Hutzler J, Snyderman SE, Cox RP 1972 Enzyme activity in classical and variant forms of maple syrup urine disease. J Pediatr 81:312

5. Danner DJ, Lemmon SK, Besharse JC, Elsas LJ II 1979 Purification and characterization of branched chain $\alpha$-ketoacid dehydrogenase from bovine liver mitochondria. J Biol Chem 254:5522

6. Dreyfus PM, Prensky AL 1967 Further observations on the biochemical lesion in maple syrup urine disease. Nature 214:276.

7. Food and Nutrition Board 1963 Evaluation of Protein Quality. National Academy of Science-National Research Council, Washington DC, Publication No. 1100

8. Howell RK, Lee M 1963 Influence of $\alpha$-ketoacids in the respiration of brain in vitro. Proc Exp Biol Med 113:660

9. Jakobs C, Solem E, Ek J, Halvorsen K, Jellum E 1977 Investigation of the metabolic pattern in maple syrup urine disease by means of glass capillary gas chromatography and mass spectrometry. J Chromatogr 143:31

10. Lancaster G, Mamer OA, Scriver CR 1974 Branched-chain alpha keto acids isolated as oxime derivatives: relationship to the corresponding hydroxy acids and amino acids in maple syrup urine disease. Metabolism 23:257

11. Langenbeck U, Hoinowski A, Mantel K, Mohring HU 1977 Quantitative gas chromatography and single ion detection of aliphatic $\alpha$-ketoacids from urine as their o-trimethylsilylquinoxalinol derivatives. J Chromatogr 143:39

12. Langenbeck U, Wendel U, Luthe H 1979 Renal clearance of branched-chain 2-oxo-acids in maple syrup urine disease. J Clin Chem Clin Biochem 17:176

13. Langenbeck U, Wendel U, Mench-Hoinowski A, Kuschel O, Becker K, Przyrembel $\mathrm{H}$, Bremer $\mathrm{HJ} 1978$ Correlations between branched-chain amino acids and branched chain $\alpha$-keto acids in blood in maple syrup urine disease. Clin Chim Acta 88:283

14. May ME, Aftring RP, Buse MG 1980 Mechanism of the stimulation of branched chain oxoacid oxidation in liver by carnitine. J Biol Chem 255:8394

15. Mitch WE, Chan W $1979 \alpha$-Ketoisocaproate stimulates branched-chain amino acid transaminase in kidney and muscle. Am J Physiol 236:E514

16. Parker PJ, Randle PJ 1978 Partial purification and properties of branched chain 2-oxo acid dehydrogenase of ox liver. Biochem J 171:731

17. Patel TB, DeBuysere MS, Barron LL, Olson MS 1981 Studies on the regulation of the branched chain $\alpha$-keto acid dehydrogenase in the perfused rat liver. J Biol Chem 256:9009

18. Pettit FH, Yeaman SJ, Reed LJ 1978 Purification and characterization of branched chain $\alpha$-keto acid dehydrogenase complex of bovine kidney. Proc Natl Acad Sci USA. 75:4881

19. Piez KS, Morris L 1960 A modified procedure for the automatic analyses of amino acids. Anal Biochem 1:187

20. Silberberg DH 1969 Maple syrup urine disease metabolites studied in cerebellum cultures. J Neurochem 16:1141

21. Snyderman SE, Boyer A, Norton PM, Roitman E, Holt LE Jr 1964 The essential amino acid requirements of infants. IX. Isoleucine. J Clin Nutr $15: 313$

22. Snyderman SE, Holt LE Jr, Smellie F, Boyer A, Westall RG 1959 The essential amino acid requirements of infants: valine. AMA J Dis Child 97:186

23. Snyderman SE, Roitman E, Boyer A, Holt LE Jr 1961 Essential amino acid requirements of infants: leucine. Am J Dis Child 102:157

24. Tashian RE 1961 Inhibition of brain glutamic decarboxylase by phenylalanine, leucine and valine derivatives: a suggestion concerning the neurologic defect in phenylketonuria and branched chain ketoaciduria. Metabolism 10:393

25. Walaitys-Rode E, Williamson JP 1980 Effects of branched chain $\alpha$-ketoacids on the metabolism of isolated liver cells. III. Interaction with pyruvate dehydrogenase. J Biol Chem 255:413 